\title{
SCHOOL OLYMPICS IN ESTONIA: NEW CHANCE OF LIFE FOR TRADITIONAL SPORTS AND GAMES?
}

\author{
Kalle Voolaid
}

\begin{abstract}
This article focuses on an interesting trend in the development of the School Olympic Games in Estonia - the use of traditional sports and games in the School Olympics programme as a means for a fresh approach to sport and education, to make the games more colourful, create a school identity and unite different cultural layers. The School Olympics - a remarkable form of the Olympic education - is currently facing serious challenges in keeping the attention of the younger generation, restoring the active life-style and reshaping moral principles. Traditional sports present a good opportunity to make a difference here. With the help of concrete examples this article gives an overview of the variety of colourful ideas used in Estonian schools, starting with popular traditional sports and ending with some newborn disciplines.
\end{abstract}

Keywords: ancient sports, School Olympic Games in Estonia, Olympic education, Olympic Games, traditional sports, traditional games

\section{NEW CHALLENGES IN OLYMPIC EDUCATION}

French educator Pierre de Coubertin, the founder of the modern Olympic Games, had a vision that the Olympic Games were not only a sports competition but also an educational and cultural event. He therefore developed a list of central educational principles of his own kind, which were influenced by individual effort and the friendly spirit of fair play. On the basis of these principles the core philosophy of the international Olympic Movement evolved, which today is introduced to the world by the International Olympic Committee (IOC) and the International Olympic Academy (IOA), with the help of Olympic education.

In today's changing world, Olympic education unfortunately faces serious challenges, losing the attention of the younger generation. Roland Naul, Olympic education expert from the University of Duisburg-Essen, Germany, summarises these main dangers as follows. 
Loss of active lifestyle. Less and less time is spent on games and sports both in daily life and in schools - together with the ongoing decline in the allocations given to physical education.

Loss of moral principles. The main characteristics here are the rise of aggression, violence and cheating, drug abuse, cultural and religious discrimination, negative changes in behavioural patterns - both in schools and in public life (Naul 2008: 164-165).

Dealing with these problems is the main goal of Olympic education today, otherwise we will just lose the battle for the Olympic principles. According to Naul (ibid.), we must restore an active lifestyle and re-shape our moral principles because without the former it is impossible to achieve the aims of the Olympic ideals and without the application of moral principles it is impossible to live by the spirit of the Olympic ideals.

It is for these reasons that the IOC, the IOA and the national Olympic committees and academies all over the world are making great efforts to find new and exciting possibilities for furthering and promoting Olympic education.

\section{SCHOOL OLYMPICS IN ESTONIA}

A quest for new educational possibilities is also pursued in Estonia. Following the positive example of some other countries, the School Olympic Games started to be organised here and soon it became the main educational project of the Estonian Olympic Academy (EOA).

The goal of the School Olympic project was to introduce the Olympic Movement to young people and give them a possibility to experience the Olympic feeling. Largely, the ideas from the Silver Springs Elementary School in Alberta, Canada, were followed (Viru et al. 1999: 25-26). At Silver Springs a real Olympic Festival was organised in the school, the Olympic topic was used in different school disciplines and festive Olympic ceremonies were organised (Binder 2012: 279-283).

The first School Olympics in Estonia, recognised by the EOA, were held at Patküla Elementary School in Tõrva on May 9-11, 1996. The programme included several exciting events: Olympic essay contest, Olympic drawing contest, contest for creating the School Olympic mascot, sports contests - and naturally the festive opening ceremony with all the "real" Olympic traditions (parade of the participants, hoisting the flag, lighting the fire, Olympic oath) (Viru et al. 1999: 25-26). 
The first School Olympics were successful to an extent and encouraged the EOA to continue the project. In 2002 it was decided to turn the project from the level of local activities to that of a nation-wide movement (Ööpik 2004: 5).

The EOA encouraged schools to organise School Olympics following the principles of the Olympic Movement and, at the same time, supported the events financially. The launch was successful, since, within the first six years of the project, School Olympics all over Estonia were held with the participation of 358 schools and kindergartens and nearly 50,000 children (Remmelkoor 2009: $17-18)$.

\section{THE MODEL OF SCHOOL OLYMPIC GAMES IN ESTONIA}

Today the guidelines of the Estonian Olympic Academy give relatively comprehensive instructions for organising School Olympics. According to these, School Olympics are not merely sports competitions, but also a cultural and educational event. An important part of it is the Olympic Education week, during which children acquire knowledge about Olympic history, the ideas of the Olympic Movement and the best athletes.

Naturally, the highlight of School Olympics is the sports festival, which follows the universal Olympics model, including the opening ceremony, sports competitions, cultural programme and closing ceremony accompanied by all the Olympic rituals (see also the EOA web page http://www.olympiaharidus. eu/index.php?page=72\&).

The participant schools have a free hand in outlining their own Olympic programmes, choosing the number and nature of the contests, sports disciplines, prizes, etc. Although the wishes, organising skills and technical possibilities of schools are on different levels, there is one common characteristic typical of Estonia - the use of traditional sports in the competitions programme. This interesting tradition has its roots in the early days of School Olympics in Estonia and - since the pioneer-games with traditional events in the programme were received very positively and emotionally - it started to spread in the hope of making the games more interesting both for the participants and the spectators. As this tradition proved its vitality, the EOA today actively recommends using non-regular sports in the programme. 


\section{EXAMPLES OF TRADITIONAL SPORTS USED IN SCHOOL OLYMPICS IN ESTONIA}

The variety of sports used at different times in different places is wide - starting with Estonian popular traditional sports, known from the innumerable summer festivals and "good mood events" (tug-of-war, traditional relays, sack race, etc.) and ending with the imitation of the traditional sports of ancient Greece (chariot race, long jump with halteres, etc.), not to mention the new colourful disciplines born out of local traditions, interests and organisers' imagination. Competitions are held even in non-sportive events like potato digging or crocheting (Remmelkoor 2008: 14). Below are examples of different sports that throughout the years have been included in the School Olympic Games, according to the categorisation given by the author.

Popular traditional sporting events in the programmes of School Olympics in Estonia: tug-of-war, stick-pulling, weight throw, boot throw, log throw, medicine ball throw, kettlebell lifting, arm wrestling, strongman contests, cartwheel rolling, wife carrying, sack race, last man's race, standing long jump, archery, dodgeball, sledge racing, snowball throwing at a target, sliding on ice.

Imitated ancient sporting events in the programmes of School Olympics in Estonia: armed race, shield race (both originating from ancient military hoplite race), chariot race, stadion race, long jump with halteres, triple jump with halteres, long jump with a shield, javelin throw, wrestling, Japanese sumo wrestling.

Newborn sporting events in the programmes of School Olympics in Estonia: pushball-football (football with a ball from pushball game), horseback racing with brooms, pillow fight, fire fighting olympics (competition for fire fighting skills), math race (running + mathematics), Formula 1 relay race, team long jump, mammoth hunt (target throwing at a mammoth figure), "Hit the nail!" (competition for hitting nails into a log), snow football, sledge slalom, sledge relay race, tandem skiing.

\section{Ancient Olympic Games in Nõo Gymnasium}

The positive impact of the first Nõo School Olympics in ancient style (held in 1999) gave an impetus to the adoption of traditional sports into the Olympic programmes in Estonia. According to the organisers, the reason for choosing the ancient style came from a desire to create their own original tradition, to do things differently and follow the ancient roots of the Olympic Games in Greece (EFA, KP 103: 95-96). 
The programme of the 1999 games in Nõo included stadion race, chariot race, weight throw, tug-of-war, sumo wrestling, shield run and pushball (ibid.). While most of these events (even Japanese sumo!) were held by the classical rules, the most attractive event - chariot race - was completely redesigned. As there were no real horses and competition chariots available, the organisers decided to use an old horse cart instead of the chariot and young boys instead of horses. Each team also had a girl for a charioteer to motivate the boys. The goal was to run one lap with the chariot around the school stadium, one by one (as there was only one chariot available) and the winner was the team with the best lap time. The extraordinary spectacular chariot race conquered the hearts of the audience and became a legend. It is still in the programme of the Nõo Games, and it is also copied by many other School Olympics in different places all over Estonia.

In 2013, the School Olympics in Nõo were already being held for the eighth time - and still in ancient style. The programme of the games has not changed much during the years and the games have become an inseparable part of the school tradition (ibid.: 98-101).

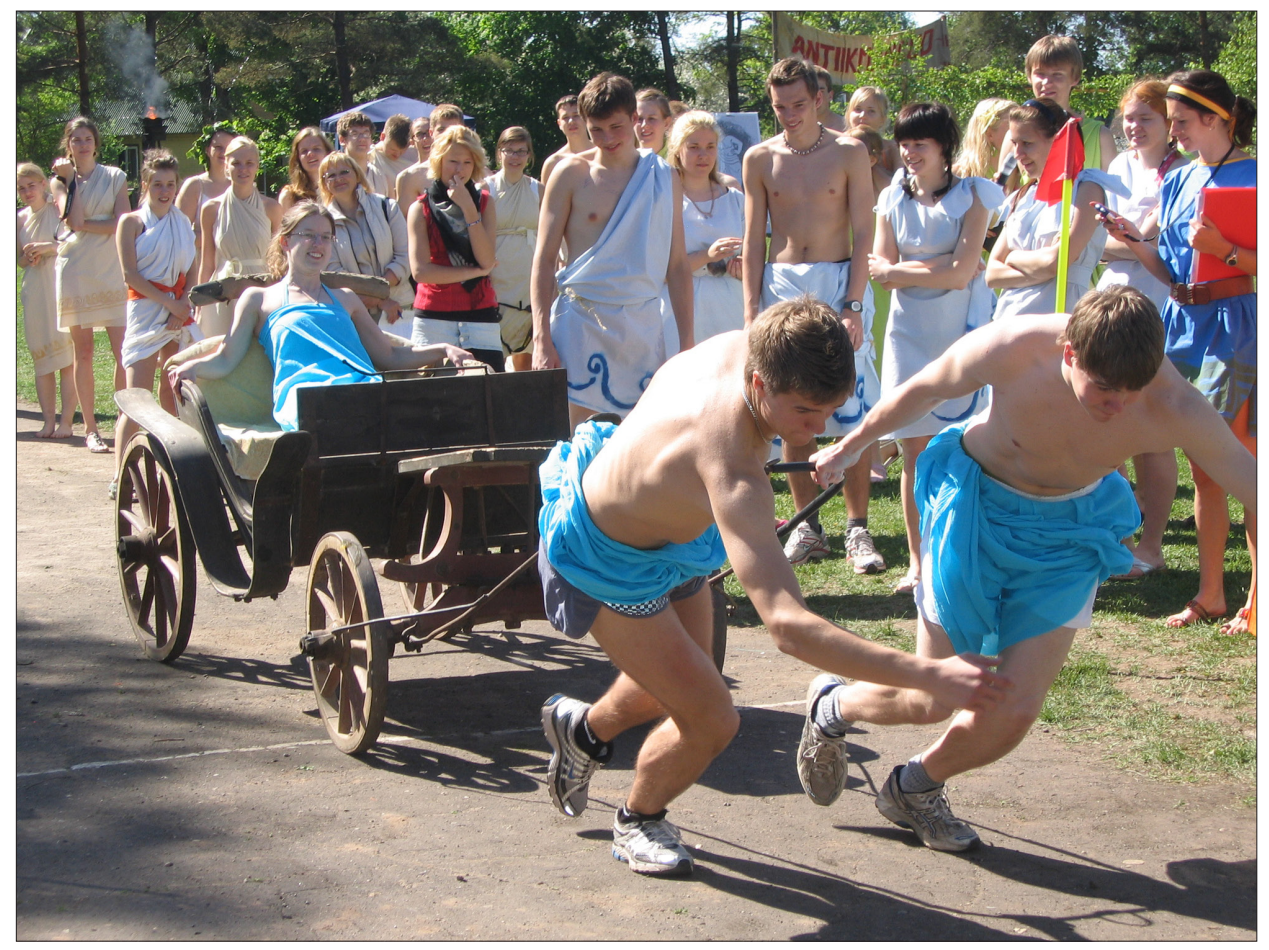

Figure 1. Ancient sport in modern style. Chariot race at Nõo School Olympic Games in 2009. Photo by Reele Remmelkoor. 


\section{School Olympic Games in Setomaa}

The School Olympic Games with a strong local cultural character are held in Setomaa, a historic region south of Lake Peipus, which is inhabited by the Seto people, an ethnic and linguistic minority group in south-eastern Estonia with their own cultural traditions. Historic Setomaa is located on the territories of present-day Estonia and Russia.

The School Olympic Games tradition in Setomaa is a good example of crossborder cultural cooperation, as along with the schools of the Estonian side of Setomaa children from Petseri (Pechory) (small town in the Russian part of Setomaa) also participate.

In 2012 the 4th School Olympic Games in Setomaa were held, with the participation of children from all the schools currently operating in the historic Setomaa area: Mikitamäe, Meremäe, Misso, Petseri and Värska. The games were an expression of the strong ethnic unity of the Seto people and their still existing respect towards their own roots. The opening words of the games were given by Aarne Leima, the sootska ('king') of the Seto people, and the Olympic flame was lit on Jumalamägi Hill (God's Hill) in Kolosova village, next to the statue of Peko, a Seto god (Lätt 2010).

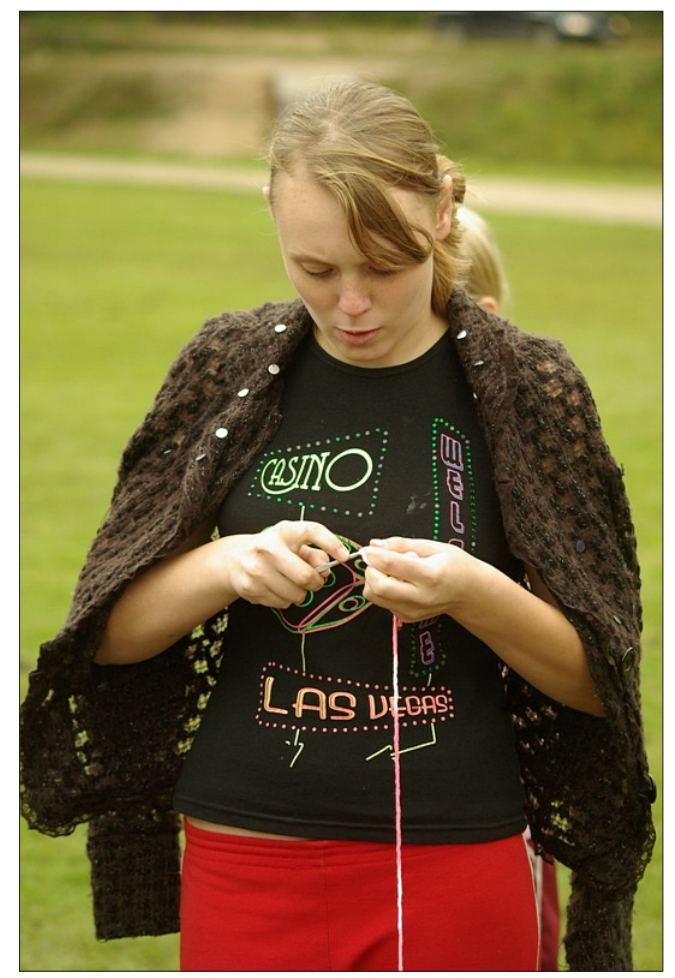

The ethnic traits of the Seto people were revealed also in the competition programme, the most attractive part of which was the electing of the Setomaa Noorik (The Maiden of Setomaa) and the Setomaa Vägilane (The Strongman of Setomaa). Both competitions consisted of a few unique events associated with the local traditions. The participants of

Figure 2. Globalising world: Seto girl, Las Vegas T-shirt, traditional jacket and crocheting competition all in one, at School Olympic Games in Setomaa in 2008. Photo by the Estonian Olympic Academy. 
the Maiden contest had to dig up a bucketful of potatoes, to demonstrate their skills in crocheting and to jump with a skipping rope, while the candidates for the Strongman title had to show their skills in different traditional heavy athletic events, such as holding dumbbells, carrying logs, etc. (see Lätt 2010).

\section{School Olympic Games on Kihnu Island}

A very special School Olympics tradition was born on Kihnu Island, a small island in the Baltic Sea. With an area of $16.4 \mathrm{~km}^{2}$, it is the seventh largest island in Estonia. The population of the island is approximately 600 people, who speak a dialect of Estonian which is sometimes considered as a distinct language. UNESCO even proclaimed the Kihnu cultural space and traditions as a Masterpiece of the Oral and Intangible Heritage of Humanity on November 7, 2003.

The first Kihnu Olympic Games were held in 2005. The programme of the first games consisted of events with both a modern and traditional character, including, for instance, stadion race, fishing net throw, race of beautiful maidens (girls running with a bowl full of water), etc. (see Võsu 2005: 2).

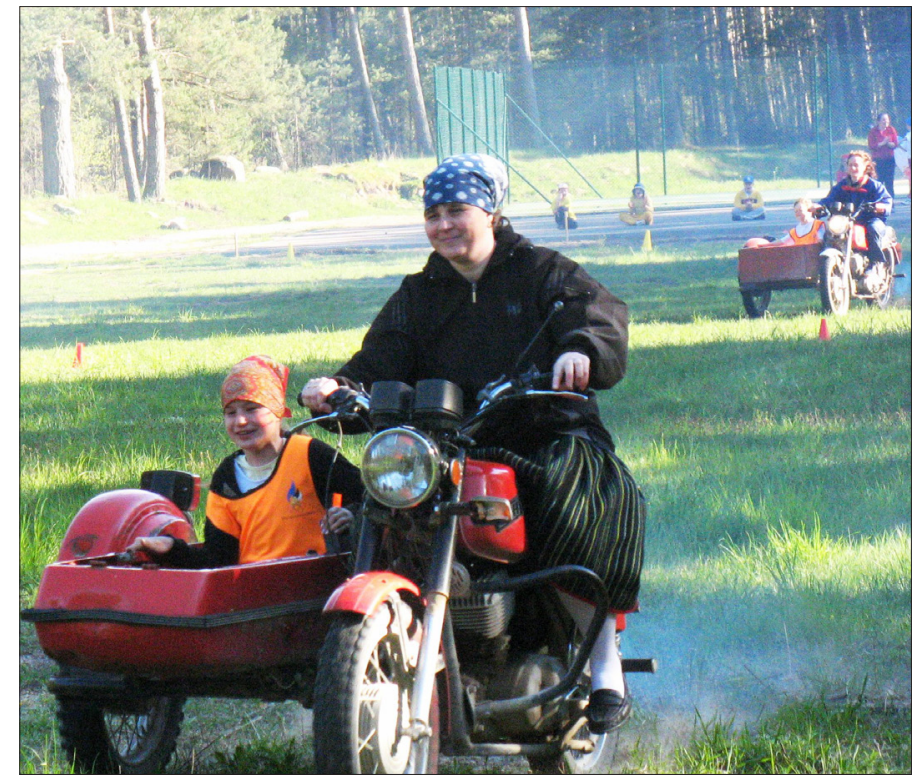

Figure 3. Kihnu woman with her child competing at the sidecar motorcycle race at Kihnu School Olympic Games in 2007. Photo by the Estonian Olympic Academy. 
History was made at the Kihnu Olympic Games of 2007 - the first sidecar motorcycle competition of the island was held, where drivers were mothers wearing their folk costumes (with beautiful long skirts) as they always do, and co-drivers were their children (Saare 2007). This unique competition was included in the games because the sidecar motorcycle is a traditional means of transport for women of Kihnu Island and is also one of the symbols of the island.

\section{Tootsi School Olympic Games}

Interesting School Olympic Games were held in Tootsi rural municipality in 2010, as a united effort of the Tootsi kindergarten and Tootsi Elementary School. These games had a literary context due to the similarity of the names of Tootsi rural municipality and one of the main characters - called Joosep Toots - in the popular novel Kevade (Spring) by a renowned Estonian writer, Oskar Luts. The organisers were encouraged to undertake this challenging task by the fact that this evergreen novel reflects the life and activities of Estonian schoolchildren.

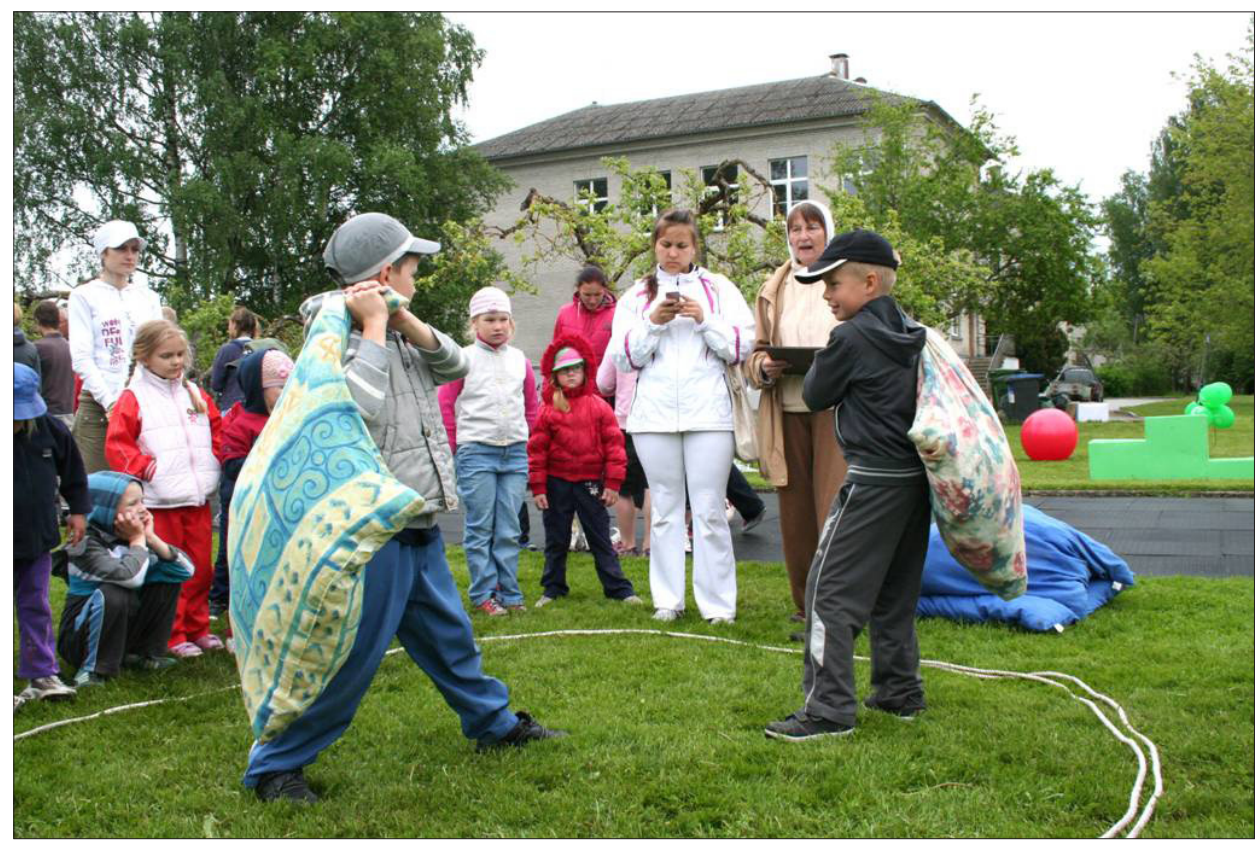

Figure 4. Pillow fight at Tootsi School Olympic Games in 2010. Photo by the Estonian Olympic Academy. 
The programme of the Tootsi Games included several competitions with names influenced by Oskar Luts's novel. The target throwing competition, for instance, was called "Hit until fixed!" (the name was derived from the popular catchphrase from the novel Kevade); the tug-of-war competition was called "Pulling Teele's braid" (Teele was the main girl-character in the novel Kevade, who was braidpulled by Toots); also there was a team event under the name "Rolling Toots's globe" (as in the novel curious Toots made a personal globe for himself), and another team event "Pass the kringle!" (as kringle with many raisins in it was one of Toots's favourite dishes) (Raudsepp et al. 2010: 1).

\section{IN CONCLUSION}

In many places of Estonia, the School Olympic Games have become an integral component of school traditions, helping to create the school identity and bind together different cultural layers. By their principles these games are more than just sport and competitions. With a different approach to sport, Olympic Games in schools can teach participants the central human values (fair play, friendship, tolerance), as well as creativeness and old national traditions.

\section{ARCHIVAL SOURCES}

EFA, KP - school lore collection of the Estonian Folklore Archives

\section{REFERENCES}

Binder, Deanna L. 2012. Olympic Values Education: Evolution of a Pedagogy. In: Educational Review, Vol. 64, No. 3, pp. 275-302, http://dx.doi.org/10.1080/0013 1911.2012.676539.

Lätt, Anneli 2010. Värskas toimusid Setomaa koolide IV olümpiamängud. [The 4th School Olympic Games in Setomaa were held in Värska.] Available at http:// www.polvamaa.ee/index.php?page $=875 \&$ action $=$ article\&article_id=15968, last accessed on July 1, 2013.

Naul, Roland 2008. Olympic Education. Oxford: Meyer and Meyer Sport.

Ööpik, Vahur 2004. Fifteen Years of the National Olympic Academy of Estonia. Acta Academiae Olympiquae Estoniae, Vol. 12, No. 1, pp. 5-6.

Raudsepp, Inga \& Põbo, Silvia 2010. 1. juunil toimusid Olümpiamängud Tootsis. [The Tootsi Olympic Games were held on June 1.] Tootsi Teataja (newsletter), No. 19, p. 1. Available at http://www.tootsi.ee/public/files/teataja20\%5B1\%5D.pdf12.pdf, last accessed on July 1, 2013. 
Remmelkoor, Reele 2008. Kooliolümpiamängud - kellele ja milleks? [School Olympic Games - For Whom and Why?] Opetajate Leht (newspaper), November 14, p. 14. Available at http://opleht.ee/arhiiv/?archive_mode=article\&articleid=539, last accessed on July 1, 2013.

Remmelkoor, Reele (comp.) 2009. Eesti Olümpiaakadeemia projekt "Kooliolümpiamängud". [Estonian Olympic Academy project "School Olympic Games".] In: Olümpiahariduse kogemused ja nü̈̈disaegsed suunad. Konverentsi teesid. [The Experiences and Modern Trends in Olympic Education: Conference Abstracts.] Tartu: Estonian Olympic Academy, pp. 17-18.

Saare, Anu 2007. Kihnu kool elas olümpialainel. [Kihnu School Was in the Olympic Mood.] Eesti Päevaleht (newspaper), May 21. Available at http://www.epl.ee/news/ eesti/kihnu-kool-elas-olumpialainel.d?id=51087700, last accessed on July 1, 2013.

Viru, Atko \& Kull, Merike \& Matsin, Tõnis \& Remmelkoor, Reele 1999. 10 years of the National Olympic Academy of Estonia. Acta Academiae Olympiquae Estoniae, Vol. 7, pp. 4-33.

Võsu, Ingrid 2005. Kihnu kooli olümpiamängud. [School Olympic Games in Kihnu.] Kyne (quarterly), June, p. 2. Available at http://kultuuriruum.ee/files/documents/ Kyne/Kyne_juuni_2005.pdf, last accessed on July 1, 2013.

\section{INTERNET SOURCES}

Web page of the Estonian Olympic Academy (EOA). Available at http://www. olympiaharidus.eu/index.php?page=72\&, last accessed on July 1, 2013. 